Volume 11

Issue 3 Global Approaches to Atrocity

Prevention: Theory, Practice, and the State of

the Field

\title{
$3-2018$
}

\section{Book Review: La Muerte del Verdugo: Reflexiones Interdisciplinarias Sobre el Cadáver de los Criminales de Masa}

Vincent Druliolle

Universidad Carlos III de Madrid

Follow this and additional works at: https://digitalcommons.usf.edu/gsp

\section{Recommended Citation}

Druliolle, Vincent (2018) "Book Review: La Muerte del Verdugo: Reflexiones Interdisciplinarias Sobre el Cadáver de los Criminales de Masa," Genocide Studies and Prevention: An International Journal: Vol. 11: Iss. 3: 134-136.

DOI:

http://doi.org/10.5038/1911-9933.11.3.1521

Available at: https://digitalcommons.usf.edu/gsp/vol11/iss3/15

This Book Review is brought to you for free and open access by the Open Access Journals at Digital Commons @ University of South Florida. It has been accepted for inclusion in Genocide Studies and Prevention: An International Journal by an authorized editor of Digital Commons @ University of South Florida. For more information, please contact digitalcommons@usf.edu. 


\title{
Book Review: La Muerte del Verdugo: Reflexiones Interdisciplinarias Sobre el Cadáver
}

de los Criminales de Masa

\author{
Vincent Druliolle \\ Universidad Carlos III de Madrid \\ Madrid, Spain
}

La Muerte del Verdugo: Reflexiones Interdisciplinarias Sobre el Cadáver de los Criminales de Masa

Séviane Garibian (ed.)

Buenos Aires, Miño y Dávila editores, 2016

266 Pages; Price: \$290 (Argentine Peso)

Reviewed by Vincent Druliolle

Universidad Carlos III de Madrid

The influence of perpetrators of massive violations of human rights does not vanish with their death. This idea is so self-evident that it hardly seems to require further research. However, La Muerte del Verdugo. Reflexiones Interdisciplinarias Sobre el Cadáver de los Criminales de Masa [The Perpetrator's Death. Interdisciplinary Reflections About Mass Murderers' Dead Bodies] takes up the challenge and sheds new light on several aspects of regime transition, transitional justice, and the politics of memory. The volume, edited by Sévane Garibian, Professor of Law at the University of Geneva and Associate Professor at the University of Neuchâtel, is a collection of chapters written by authors from various backgrounds (historians, legal scholars, anthropologists, psychologists, novelists) that brilliantly succeeds in drawing our attention to fascinating but hitherto neglected issues.

In the volume's introduction, Garibian underscores that while the literature has extensively discussed the question of the death and burial of victims of mass violence, analysing the perpetrators" dead body is "a taboo within the taboo itself" 1 insofar as their death is hardly discussed in the first place. Garibian introduces the three main questions around which the chapters are articulated, namely the circumstances of the perpetrator's death, "what to do with their remains?" and "how to approach their legacy, the memory of their person and of their crimes?," or their "patrimonialization." ${ }^{2}$ The first question is used to divide the book into three sections ("natural death," "judicial execution" and "extrajudicial killing") that analyse case studies from various geographical areas and historical periods. These are preceded by a discussion of the legality of tyrannicide in international law. The status of this chapter as prologue seems rather odd since it is only related to the third kind of perpetrator's death. Including it in the third part of the volume would have made more sense as it complements the other chapters, in particular those about the death of Osama bin Laden and Muammar Gaddafi.

All the chapters are very informative and well-written, though their degree of engagement with the issues outlined in the introduction and analytical depth varies. The first section of the volume is entitled "Natural death, death under suspicion" to stress that its causes are often contested or questioned (which may be used to present perpetrators as victims of injustice or conspiracy), but also the fact that it means that perpetrators escape justice and accountability. The section includes chapters about Pol Pot, Jean-Bédel Bokassa and Idi Amin Dada, Francisco Franco and Augusto Pinochet, and Slobodan Milošević. The chapters about the Cambodian and African dictators recount the circumstances of their death and explain how cultural and religious beliefs, some of which pertain to the dead body, have shaped their surprisingly merciful memories. The consequence of the perpetrator's natural death are well highlighted by Milošević's fate. Because he died in prison a few days before the end of his trial, the truth about his role in the Balkan Wars could not be officially established. Florence Hartmann refers to his "posthumous victory"3 insofar

\footnotetext{
${ }^{1}$ Séviane Garibian, "Introducción: La muerte del verdugo o el tiempo incontable de su eternidad," in La Muerte del Verdugo. Reflexiones Interdisciplinarias Sobre el Cadáver de los Criminales de Masa, ed. Séviane Garibian (Buenos Aires: Miño y Dávila editores, 2016), 25. 
as Milošević will enjoy perpetual impunity, the truth about his crimes will remain partial, his responsibility can still be denied, and both the victims' work of mourning and reconciliation are significantly hindered. In other words, he "wins several of the battles he had fought during his life [...] [and ends up killing] Justice and Truth."4 Milošević's dead body reflects how his death represents a way out (muerte-escapatoria): ${ }^{5}$ no picture was ever seen and uncertainty surrounds the site where Milošević is buried. Finally, the contribution by Rosa Ana Alija Fernández further explores the relationship between the perpetrator's dead body, truth and justice by comparing the deaths of Franco and Pinochet. The author highlights the direct relationship between the dictator's dead body and the struggle for human rights and against impunity in both cases. Franco is buried in a huge monument outside Madrid, el Valle de los Caídos (the Valley of the Fallen). Franco himself had ordered its construction to celebrate his victory in the Civil War (1936-1939) and the works to build it entailed the death of hundreds of Republican prisoners. Over the past two decades, several actors have requested the transfer of Franco's remains to another site in an attempt to recover the site and resignify it, which has proved impossible. Alija Fernández argues that Franco's mortal remains symbolise the lack of a break with the past that characterised the Spanish transition to democracy, and the legacy of the dictatorship in contemporary Spain. She astutely observes that the demands to transfer Franco's body have increased since Spanish courts ruled out the possibility of judging his crimes, "as an alternative way of putting a symbolic end to impunity." 6 On the other hand, though Pinochet had plans to have his own Valle de los Caídos built in Chile, he later decided that his ashes would remain in a family mausoleum. Stressing the contrast with Franco, the author underlines that the choice of a private burial site is the consequence of the political and judicial struggle for memory and justice in Chile.

The second section focuses on judicial executions and has only two chapters. While the chapter about Saddam Hussein's death focuses mainly on the religious symbolism surrounding the execution of "the Butcher of Baghdad" and the meanings of the footage of the event, Nicolas Patin offers a historical perspective on the issues surrounding the treatment of the perpetrators' dead bodies by analysing the debates about the execution of the Nazi leaders sentenced to death after the Second World War. He shows that the public character of the execution was seen as necessary to avoid transforming perpetrators into martyrs and to symbolise the birth of a new political system. Patin also critically engages with the idea that incinerating the perpetrators' bodies and denying them a burial (site) may prevent turning them into cult figures.

Finally, the third section is about extrajudicial killings or "death as vengeance." Garibian is interested primarily in the meaning and significance of the trial that led to the acquittal by a German tribunal of the survivor of the Armenian genocide who killed Mehmet Talaat Pasha. The following chapter by Didier Musiedlak about the mystery surrounding Mussolini's death is very detailed but fails to engage with the issues raised in the volume's introduction. In her chapter, Muriel Montagut is critical of the media and political leaders' silence (or, rather, silent relief) following the lynching of Muammar Gaddafi. She claims that the failure to condemn the cruelty of his death and the degrading display of his body in an industrial freezer turns us from distant witnesses into indirect accomplices and does not augur well for post-Gaddafi Lybia. The most challenging and theoretically sophisticated chapter of the third section is Frédéric Mégret's analysis of the "fugitive death" of Osama Bin Laden. Drawing on Foucault, he argues that it is a practice that constitutes and legitimises the knowledge and techniques of the so-called War on Terror at the same time as it reaffirms the state's sovereign power.

The chapters in La Muerte del Verdugo draw important lessons summarised by Garibian in the introduction: "Natural death [...] 'makes [perpetrators] more human' but does not repair. Judicial execution [...] condemns but does not demystify. [Extrajudicial killing] [...] dishonours

Sobre el Cadáver de los Criminales de Masa, ed. Séviane Garibian (Buenos Aires: Miño y Dávila editores, 2016), 135.

${ }^{4}$ Ibid., 139.

${ }^{5}$ Ibid., 135-9.

${ }^{6}$ Rosa Ana Alija Fernández, “El inextricable camino entre el lecho de muerte y la lucha contra la impunidad: los casos de Franco y Pinochet," in La Muerte del Verdugo. Reflexiones Interdisciplinarias Sobre el Cadáver de los Criminales de Masa, ed. Séviane Garibian (Buenos Aires: Miño y Dávila editores, 2016), 111. 
but does not pacify." ${ }^{7}$ Besides, although it depends on a multiplicity of factors, the posthumous transformation of perpetrators into cult figures is almost inevitable. ${ }^{8}$

The book is very enjoyable to read, though readers will likely lament the fact that it does not include any pictures, which would have been particularly appropriate. The volume's main weakness is the confusion about what the chapters actually focus on. Indeed, some of them are not so much about the perpetrators' dead body-the book's central theme-as about the pictures or footage that immortalise it, the perpetrators' grave or memorial, or simply his/her death. Nevertheless, this may be one of the defects of volumes such as La Muerte del Verdugo that are innovative and truly interdisciplinary contributions to the existing scholarship.

\footnotetext{
${ }^{7}$ Sévane Garibian, "Introducción: La muerte del verdugo o el tiempo incontable de su eternidad," in La Muerte del Verdugo. Reflexiones Interdisciplinarias Sobre el Cadáver de los Criminales de Masa, ed. Séviane Garibian (Buenos Aires: Miño y Dávila editores, 2016), 33.

${ }^{8}$ Ibid., 34.
} 